\title{
MOVING RESEARCH ON INTERNATIONAL NEW VENTURES FORWARD: A SYSTEMATIC REVIEWS ON CASE STUDIES
}

Pablo Leão ${ }^{1}$, Renato Souza Santos

Fundação Getúlio Vargas - FGV, São Paulo, (Brasil)

\begin{tabular}{l} 
ARTICLE DETAILS \\
\hline Article history: \\
Received: 01 September 2020 \\
Accepted: 30 March 2021 \\
Available online May: 01 th 2021 \\
Double Blind Review System \\
Scientific Editor \\
Ilan Avrichir \\
\hline Keywords \\
International entrepreneurship \\
International new ventures \\
Rapid internationalization \\
Born global \\
Micro multinational
\end{tabular}

\section{Introduction}

The internationalization of firms is a topic widely explored, and the first theories date from the 1950s. However, a new pattern of internationalization of small and medium-sized firms has been calling the attention of researchers and practitioners since 1993, when Rennie's seminal article coined the term "bornglobal firms."

Oviatt and McDougall (1994) re-signified this term and brought attention to International New Ventures (INVs), combining entrepreneurship theories to explain these new business models. For the authors, INVs are businesses that, from their foundation, seek to derive significant competitive advantage from the use of resources and the sale of outputs in multiple countries. In general, the entrepreneurs are internationally experienced and able to link resources derived from various countries to meet the demand of international markets.

Further research explored the rapid internationalization process, and other terms were associated with it, with few conceptual differences among them: micro-multinationals, global firms, global startups, and so on. The contrariety about this concept is not only within the nomenclature but is also found in the fundamental aspects that define an INV (Welch, Rumyantseva, \& Hewerdine, 2016). The current literature extensively disagrees about the time of inception, the relevance of international sales and presence in different markets (Arenius, Sasi, and 
Gabrielsson, 2005; Gabrielsson, Sasi, and Darling, 2004; Knight and Cavusgil, 2004; McDougall, 1989; Mort and Weerawardena, 2006).

Edmondson and McManus (2007) suggest that developing theories, such as the one under scrutiny, demand qualitative research to identify patterns, generate insights about a novel phenomenon, and identify gaps in existing theory. Therefore, qualitative methodologies such as case studies can serve this research topic by focusing on the dynamics of a single setting (Eisenhardt, 1989). Moreover, it can contribute to theory development as this intimate contact with empirical reality allows developing testable, relevant, and valid theories (Glaser \& Strauss, 1967).

Therefore, through a systematic review, we aim to understand how the INVs have evolved through the lens of case studies? Recent reviews have focused on bibliometric analysis (Dzikowski, 2018), performance (Jiang et al., 2020) and, a broader approach to the phenomena (Romanello \& Chiarvesio, 2019). Our study adds to the previous research by offering a thematic analysis based only on case studies. We contribute to the literature by summarizing and discussing the most relevant themes researched within the INVs area. On that note, our study demonstrates how the literature has evolved through case studies. We also highlight the use of INVS' concepts still disregards the criteria found in the seminal literature. Most studies are not considering the implications of applying the concepts interchangeably or adding and dropping criterias when selection cases. We discuss some of the implications such practice has to the theory development.

The article is organized into six sections: the first comprises this introduction; the second presents the theory upon which this article relies; the third explores the methodology; the fourth part includes the results with the overall analysis and the thematic analysis; the fifth we present a discussion of those results and suggest a future agenda. The final section presents the conclusions.

\section{Overview of rapid internationalization}

At the end of 1980, young businesses facing a resource-constraint scenario associated with a rapid internationalization process emerged. This phenomenon no longer complied with the existing incremental theories of internationalization (Johanson \& Vahlne, 1977). Thus, in the junction of international business literature and entrepreneurship, a new discussion started, generating a new research field, named International Entrepreneurship (McDougall, 1989; Verbeke and Ciravegna, 2018; Zander, McDougall-Covin, and Rose, 2015). Two concepts emerged to explain such phenomena. McDougall (1989) introduced the definition of international new ventures (INVs) (McDougall, 1989, p. 387). Later, the concept of born global emerged to explain similar phenomena (Rennie, 1993), and a new study came out to refine the idea behind the international new venture (Oviatt \& McDougall, 1994). Since then, international new ventures (INV's) and born global (BG) have been the two most used concepts to explain the phenomena of rapid internalizing firms (Verbeke \& Ciravegna, 2018).

The INVs are small firms that engage in the international market from or near their inception (Knight \& Cavusgil, 2004; Oviatt \& McDougall, 1994; Rennie, 1993), and they are "expected to exhibit compressed internationalization stages in a relatively short time span" (Hashai \& Almor, 2004, p. 15). Although the literature is quite diverse, a broad definition commonly used is the one proposed by Oviatt and McDougall (1994) - "a business organization that, from inception, seeks to derive significant competitive advantage from the use of resources and the sale of outputs in multiple countries." Despite meeting the authors' goal in describing the phenomena, this definition fails to provide a more straightforward concept of the term regarding its operationalization since the authors do not set any boundaries for classification (Bader \& Mazzarola, 2009). With the expansion of the field, new concepts emerged such as "global-start-ups" (Mathews, 2006; Oviatt \& McDougall, 1994), micromultinationals (mMNEs) (Dimitratos, Johnson, Slow, \& Young, 2003), and "born-again-globals" (Bell, McNaughton, Young, \& Crick, 2003).

Along with the new concepts, studies introduced several attributes to characterize early internationalizing firms. In this matter, Dib et al. (2010) identified some features for born global firms, such as the internationalization pace, which can vary from 2 years (Moen, 2002) up to 15 years (Gabrielsson, Gabrielsson, \& Dimitratos, 2014); the relevance of the international activity (mainly exports) in total sales - varying from at least 5\% 
percent (McDougall, 1989) to a minimum of $25 \%$ (Knight \& Cavusgil, 2004); and the geographical scope of the operations, which for Sharma and Blomstermo (2003) means the presence of the new venture in one or few international markets, while for Gabrielsson et al. (2004) the presence must be in various regions of the world. Quantitative tests have suggested that an INV risk fail negatively affects the international scope. This relationship is moderated by entrepreneurial orientation (Jean, Kim, \& Cavusgil, 2020). The interchangeably and improper use of INV and BG concepts (Coviello, 2015) and the myriad of concepts with loose definitions made it difficult to operationalize the concept of INVs.

Aiming to clarify how the field is organized, we developed a framework that is presented in Figure 1.
Because the INV concept offers a broader definition of the early internationalizing firm, we assume it comprises micro-multinationals, born global and global startups (Coviello, 2015; McDougall, Shane, and Oviatt, 1994). Thus, from this moment forward, we will refer to the "early internationalize firms" as INVs. Welch, Rumyantseva and Hewerdine (2016) add to this discussion, affirming that certain theoretical movements end up generating possibilities for new classifications and, therefore, more categories with several other variances to fit all the possible cases in the IE literature. However, this movement cannot be driven by empirical convenience; it instead must evolve based on the careful justification that considers both theoretical and empirical grounds.

Figures and Table

Figure 1 - Conceptual Framework

\section{International Entrepreneurship}

"[...] development of international new ventures or start-ups that, from their inception, engage in international business, thus viewing their operating domain as international from the initial stages of the firm's operation" (McDougall, 1989).

\section{International New Venture}

A business organization that, from inception, seeks to derive significant competitive advantage from the use of resources and sale of outputs in multiple countries by coordinating multiple value chain activities across borders (Oviatt \& McDougal, 1994).

\section{Important characteristic}

- Coordinate activities abroad from inception or soon after, usually within 3 years of inception.

\begin{tabular}{|c|c|c|}
\hline $\begin{array}{l}\text { Micro Multinationals } \\
\text { mMNEs are smaller firms that } \\
\text { employ advanced (non-exporting) } \\
\text { foreign market servicing modes to } \\
\text { tap into opportunities abroad. } \\
\text { (Dimitratos, Johnson, Slow\& Young; } \\
\text { 2003) } \\
\text { Important characteristics } \\
\text { - Use advanced entry modes (e.g., } \\
\text { joint ventures) }\end{array}$ & $\begin{array}{l}\text { Global Start-ups } \\
\text { It is the most radical manifestation of } \\
\text { the international new venture that } \\
\text { pursues opportunities from the } \\
\text { moment it is discovered (McDougall, } \\
\text { Shane and Oviatt, 1994). } \\
\text { Important characteristics } \\
\text { - Presence in multiple countries } \\
\text { from inception }\end{array}$ & $\begin{array}{l}\text { Born Global Firms } \\
\text { Business organizations that, from or near } \\
\text { their founding, seek superior international } \\
\text { business performance from the application } \\
\text { of knowledge-based resources to the sale } \\
\text { of outputs in multiple countries } \\
\text { (Knight \& Cavusgil, 2004). } \\
\text { Important characteristics: } \\
\text { - Focus on export sales } \\
\text { - Interationazation intensity (more than } \\
25 \% \text { in sales) }\end{array}$ \\
\hline
\end{tabular}


Despite the broad and loose definition of concepts, studies on international new ventures have provided several insights into those firms' internationalization processes. The field has evolved, and it is possible to notice some convergence among authors to understand this process. Those firms' internationalization is usually driven by the need to go abroad as means of survival due to the smallness of their home market (Kumar \& Yakhlef, 2014). The idea of opportunity exploitation (Oviatt \& McDougall, 2005 ) is central in this process (Jones, Coviello, \& Tang, 2011; Mainela, Puhakka, \& Servais, 2014) because those firms depend on the ability to identify and exploit opportunities to develop innovation across the value chain (Cavusgil \& Knight, 2015; Reuber, Knight, Liesch, \& Zhou, 2018). Due to their size, INVs are usually constrained by resource scarcity, which can challenge early internationalization (Coviello and Cox, 2007; Guo and Wang, 2020; Laudien and Daxböck, 2017) and drive companies to seek it in the international market (Cannone, Pisoni, \& Onetti, 2014).

The theory has also suggested the ability the fostering and management of a network are essential not only in the inception (Brouthers, Geisser, and Rothlauf, 2016; Coviello and Cox, 2007) but also to guarantee the firm's survival (Freeman, Edwards, \& Schroder, 2006). Although the organization level has received much attention, a relevant stream of this field emerged in parallel, focusing on the individual level to understand the role of the entrepreneur/founder. The entrepreneurial orientation can drive early internationalization (Mathews \& Zander, 2007). Entrepreneurial characteristics such as global mindset, international experience, risk-taking, and proactiveness have been noticed as relevant in the process of early internationalization (Gabrielsson et al., 2014). Wadeson (2020) highlights that entrepreneurs with previous internationalization experience are more resilient. Such resilience can reduce the entrepreneurs' risk aversion to further commit to the internationalization process.

Building upon the existing literature, we aim to analyze how the collective knowledge on international new ventures has evolved through the case-study methodology. We have focused on case studies because it is a qualitative research method extensively used in social science to confirm, challenge, or extend a given theory. It is appropriate to understand a real-life phenomenon in depth and situated in its context (Yin, 2009). Despite its contribution to theory building, the method has limitations. As any other qualitative method case studies have limited generalization power, it can describe a very idiosyncratic phenomenon to the point that cannot be raised to the level of theory development (Eisenhardt, 1989). Moreover, its context embeddedness, cross-analysis, and replication aim (Eisenhardt, 1989; Yin, 2003) requires close attention to the case selection phase.

Case studies design can vary in paradigms, approaches, and design. It allows researchers to analyze phenomena from positivistic to the constructivist paradigm, and it can be deductive, abductive, or inductive. Case studies design can include only one case (single) or several (multiple). It can vary in time (longitudinal) and have several levels of analysis (Yin, 2009). The most common case study strategy in management is proposed by Eisenhardt (1989) and (Yin, 2009).

However, competing designs are also applied. Single case studies aim to investigate processes, events, or phenomena in-depth. It is intrinsically embedded in its context (Stake, 1998), not necessarily seeking better constructs but providing a deeper understanding of the context (Dyer \& Wilkins, 1991). It can be exemplary and revelatory (Yin, 2009), and it should richly describe a phenomenon; therefore, the choice of the case cannot be random (Siggelkow, 2007).

Case study strategy allows theory building through cases embedded in its context. The theoretical sampling offers an opportunity to extend and challenge the theory. It also provides a tick description of the cases. All those aspects make it an exciting method to understand how the theory of international new venture has evolved, allowing us to critically analyze the correct use of concepts and its implication.

Thus, we conduct a literature review selecting only case studies. This approach differs from previous literature reviews (Dzikowski, 2018; Ibeh, Jones, \& Kuivalainen, 2018; Jiang et al., 2020; Nardali, 2017; Øyna \& Alon, 2018; Tuomisalo \& Leppäaho, 2019) in different ways: (1) in scope - we include studies from the broad area of management, not focusing only on 
international business and entrepreneurship; (2) in objective - we conducted a systematic review with a thematic analysis aiming to offer a broad overview on how the field has evolved; and (3) in design - by selecting only case study we can further the understanding on how the concept is being operationalized through a specific method.

\section{Research Method}

Aiming to understand how the rapid internationalization phenomena have been developed through the lenses of case studies, we perform a systematic review. A systematic review is a replicable, scientific and transparent process that aims to identify key scientific contributions to a field or question (Tranfield, Denyer, \& Smart, 2003), thus aligned to the objective of this paper. We proceed with this review in three steps: data collection, data analysis, and synthesis (Crossan \& Apaydin, 2010). To guide our analysis, we set the following research question: what have we learned about rapid internationalization through case studies? In the following sections, we explain the process we followed.

\subsection{Data collection}

Following previous reviews and aligned with this research's objective, we limited our data sources to peer-reviewed journals, as these are acknowledged to have high impacts on social science (Podsakoff, Mackenzie, Bachrach, \& Podsakoff, 2005). We searched in two databases - Scopus and Web of Science, which indexes more than 55,000 peer- reviewed journals. Because we aim to understand the development of a specific concept, the search in the databases was performed using a set of keywords that encompasses the phenomena of rapid internationalization and the case study method: "BORN GLOBAL" OR "NEW INTERNATIONALIZING FIRM" OR "INTERNATIONAL NEW VENTURE" OR "INTERNATIONAL ENTREPRENEURSHIP" OR "RAPID INTERNATIONALIZING" OR "GLOBAL START*" OR MICRO* MULTINATIONAL* AND "CASE* STUD*." The result was then filtered to allow published peerreviewed articles only. We did not limit the search by date nor area of knowledge because we recognized the phenomena had been widely studied across different schools of knowledge.

After retrieving all articles from both databases, we merged the results and excluded the repeated ones. We then select only articles published in journals listed in the 2018 Academic Journal Guide published by the Chartered Association of Business Schools (CABS-AJG2018). This criterion was chosen because top journals usually publish high-quality papers. It has been applied in previous reviews as a quality criterion for paper selection (e.g., Crossan and Apaydin, 2010; Tawse and Tabesh, 2021). To assess the relevance of each paper to the objective of this review, both authors read the abstract, introduction, and method to decide whether it should be kept. A list of criteria for inclusion and exclusion was defined to guide our decision. Figure 2 illustrates the whole process of selection. Thus, the final sample of 99 articles was deeply analyzed and systematized into categories. In the next session, we thoroughly explain our process of analysis and synthesis. 
Figure 2 - Articles selection process

\begin{tabular}{|c|c|c|c|}
\hline $\begin{array}{c}\text { Web of } \\
\text { Science } \\
\text { Feb 9th } \\
2021\end{array}$ & \multicolumn{2}{|c|}{$\begin{array}{l}\text { TÓPICO: (( "BORN GLOBAL" OR "NEW INTERNATIONALIZING FIRM" OR } \\
\text { "INTERNATIONAL NEW VENTURE" OR "INTERNATIONAL } \\
\text { ENTREPRENEURSHIP" OR "RAPID INTERNATIONALIZING" OR "GLOBAL } \\
\text { START*" OR "MICRO* MULTINATIONAL")) AND TÓPICO: ("CASE* STUD*") } \\
\text { Refined for: TIPOS DE DOCUMENTO: (ARTICLE ) }\end{array}$} & 117 \\
\hline $\begin{array}{c}\text { Scopus } \\
\text { Feb 9th } \\
2021\end{array}$ & \multicolumn{2}{|c|}{$\begin{array}{l}\text { TITLE-ABS-KEY (("BORN GLOBAL" OR "NEW INTERNATIONALIZING FIRM" } \\
\text { OR "INTERNATIONAL NEW VENTURE" OR "INTERNATIONAL } \\
\text { ENTREPRENEURSHIP" OR "RAPID INTERNATIONALIZING" OR "GLOBAL } \\
\text { START*a OR "MICRO* MULTINATIONAL*") AND "CASE* STUD*") AND ( } \\
\text { LIMIT-TO ( DOCTYPE,"ar" )) }\end{array}$} & 216 \\
\hline \multicolumn{4}{|c|}{ After excluding repeated articles $=254$} \\
\hline \multicolumn{4}{|c|}{ Filtered by ranked journals in the CABS-AGJ2018 $=197$} \\
\hline \multicolumn{4}{|c|}{ iment with research questions $=99$} \\
\hline \multicolumn{2}{|r|}{ Inclusion criteria } & \multicolumn{2}{|l|}{ Exclusion criteria } \\
\hline \multicolumn{2}{|c|}{$\begin{array}{l}\text { Assessment of articles alignment with the } \\
\text { research question } \\
\text {-The article focuses on rapid or accelerated } \\
\text { internationalization. } \\
\text {-The article's methodology is based on case } \\
\text { study. } \\
\text { - The article present SOME of the criteria that } \\
\text { define an international new venture firm, or the } \\
\text { article clearly state the case is based on } \\
\text { international new venture firm according to the } \\
\text { criteria defined in the literature (see figure 1). }\end{array}$} & $\begin{array}{l}\text { Assessment of articles alignment with } \\
\text { research question } \\
\text { - The article is not focused on } \\
\text { internationalization. } \\
\text { - The article is not clear on } \\
\text { conceptualization of international } \\
\text { venture. } \\
\text { - The article does not present ANY of } \\
\text { criteria that defined an international } \\
\text { venture firm, NOR clearly state the ca } \\
\text { based on an international new venture } \\
\text { according to the criteria defined in } \\
\text { literature (see figure 1). } \\
\text { - The article does not present } \\
\text { methodology procedures. }\end{array}$ & $\begin{array}{l}\text { the } \\
\text { rapid } \\
\text { the } \\
\text { new } \\
\text { f the } \\
\text { new } \\
\text { se is } \\
\text { firm } \\
\text { the } \\
\text { the }\end{array}$ \\
\hline
\end{tabular}

\subsection{Data analysis}

For the reviewing process, we performed qualitative data analysis. Thus, we followed a twocycle coding (Miles, Huberman, \& Saldana, 2014; Saldaña, 2013) which helped us narrow down and aggregate the data collected and emerge the final categories for thematic analysis (Braun \& Clarke, 2006). In the first cycle, we used a holistic coding approach because it allowed us to categorize the articles' objectives and findings into basic themes. In the second cycle of coding, we drew from a theoretical coding approach because it allows close alignment with concepts (Corbin \& Strauss, 2008) in the literature of rapid internationalization. We add theming coding to the second cycle so the initial categories could be cohesively merged into a final set of categories that best captures, unifies, and organizes repeated ideas within the data we analyzed (DeSantis \& Ugarriza, 2000; Saldaña, 2013). This 


\section{3}

Moving Research on International new Ventures Forward: A Systematic Reviews on Case Studies

approach is in line with our aim to provide an overview of how rapid internationalization has been evolving through case studies methodology.

\section{Overall analysis}

Our review of the articles commenced with an initial analysis of each publication, related to where and when it was published, country and sector under scrutiny, the methodological approach for case studies (single or multiple), and the articles' main topic. Although we did not restrain our search by date of publication, the oldest article is from 2005. Most articles were published between 2010 and 2020. The final sample includes 99 articles from 42 Journals within 8 management fields. Despite the relevance of the topic, we noticed the production rhythm has dropped over the years.

Figure 3 depicts the articles per research area. Most articles are published in Entrepreneurship (46), being Journal of International Entrepreneurship, the journal with almost half of those publications (20). Followed by the International Business area (23) and the Marketing area (16). The more fragmented areas are Ethics (8), Innovation (3), Human Resources (1), Strategy (1), and Information Management (1). These results confirm the interaction among research fields and the interest in studying several facets of INVs.

Figure 3 - Publications by research field

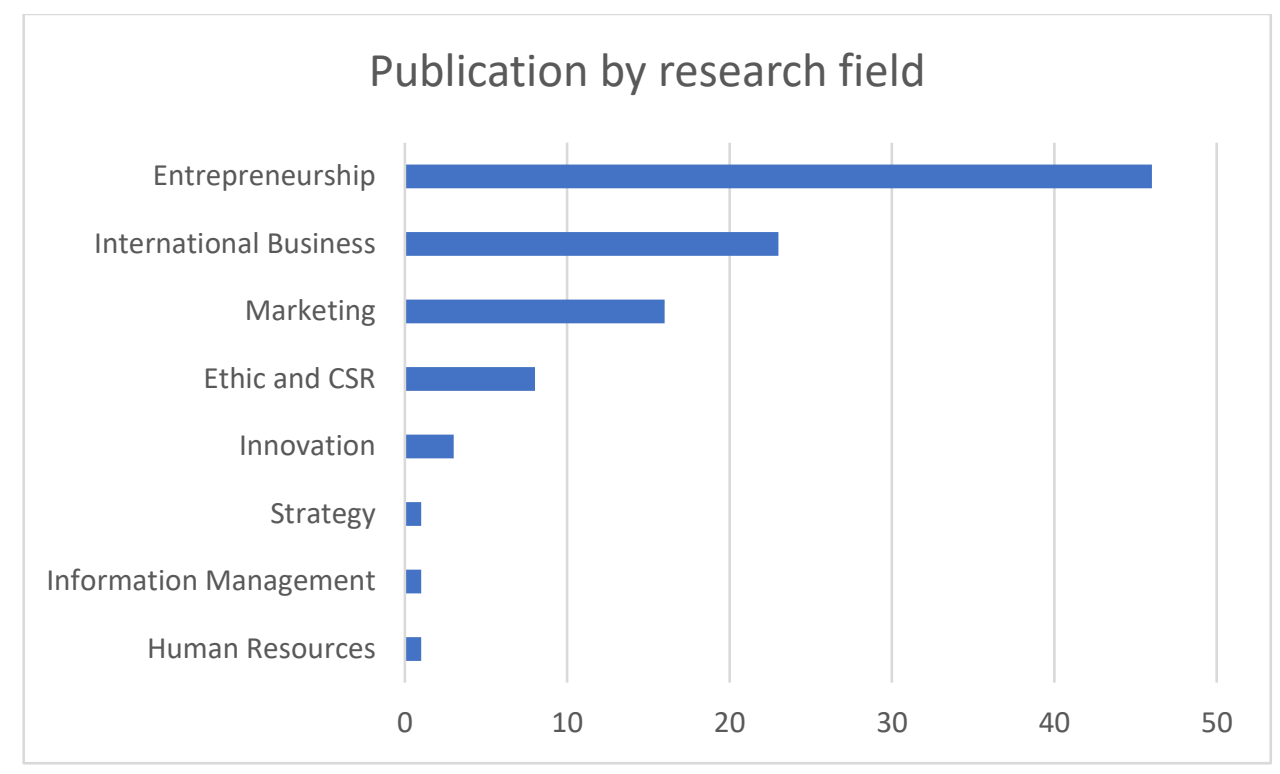

Within our sample, $76 \%$ of the articles analyze the case of companies whose home country is developed and $21 \%$ from emerging countries. Looking at the destination countries, we see that $58 \%$ go to developed countries, while only $6 \%$ go to emerging countries. In Table 1, we present a summary of the cases. 
Table 1 - Case sample summary

\begin{tabular}{l|c|c}
\hline Research cases & & \\
\hline Total & $\mathrm{N}$ & $\%$ \\
\hline Article & 99 & \\
\hline Cases within articles & 473 & \\
\hline Case Sample & & \\
\hline Single & 32 & $32 \%$ \\
\hline Multiple & 67 & $68 \%$ \\
\hline Home Country report & & \\
\hline Develop & 75 & $76 \%$ \\
\hline Emerging & 21 & $21 \%$ \\
\hline Both & 0 & $0 \%$ \\
\hline n.a. & 3 & $3 \%$ \\
\hline Host Country report & & \\
\hline Develop & 57 & $58 \%$ \\
\hline Emerging & 6 & $6 \%$ \\
\hline Both & 13 & $13 \%$ \\
\hline n.a. & 23 & $23 \%$ \\
\hline
\end{tabular}

Note: $n . a .=$ not avaliables in article

Many papers do not correctly report relevant information on the cases, which implicates the replication and comparability of findings. Table 2 illustrate how the articles approach each of the concepts and the information they do not inform. Regarding the use of the concept, there is a balance between INV (46) and BG (43), the use of MMNE is scarce (3), and others use it interchangeably INV/BG (7). We also found three articles on mMNE and none about global startups. The ongoing interchangeable use of INV and BG demonstrates the concepts still being stretched and wrongly applied (Coviello, 2015).

Table 2 - Case report analysis

\begin{tabular}{l|l|c|c|c|c|c|c}
\hline & & Home Country & Host Country & Pace & Entry Mode & $\%$ Sales & Total Articles \\
\hline INV & Correct report & 43 & 36 & 44 & 18 & 12 & 46 \\
\hline & Not avaliable & 3 & 10 & 2 & 28 & 34 & \\
\hline BG & Correct report & 43 & 35 & 38 & 39 & 19 & 43 \\
\hline & Not avaliable & 0 & 8 & 5 & 4 & 24 & \\
\hline BG/INV & Correct report & 7 & 3 & 5 & 5 & 2 & 7 \\
\hline & Not avaliable & 0 & 4 & 2 & 2 & 5 & \\
\hline mMNE & Correct report & 3 & 2 & 3 & 3 & 2 & 3 \\
\hline & Not avaliable & 0 & 1 & 0 & 0 & 1 & \\
\hline
\end{tabular}

For instance, some articles (3) do not report the INV home country location (Sainio, Saarenketo, Nummela, \& Eriksson, 2011). Others do not inform the target market (18). As we previously mentioned, case studies are context embedded (Eisenhardt, 1989; Stake, 1998; Yin, 2003). Thus, the findings are inherently related to the characteristics of companies' locations. By not reporting on the target market, those articles also refrain from the possibility that those companies can be global startups (Oviatt \& McDougall, 1994). We also found cases that do not provide information on internationalization pace (9) 
(Hohenthal, 2006; Kontinen \& Ojala, 2011; Kungwansupaphan \& Siengthai, 2014; Pettersen \& Tobiassen, 2012; Sainio et al., 2011). Some of those articles briefly support their case selection by only informing the case that companies "internationalize soon after the inception."

The lack of detailed information such as date of foundation, date of internationalization, or the company's time to initiate its international activities open up two fundamental issues: (1) are those companies an INVs? (2) how fast are those companies internationalizing? Such aspect is central to INV theory (Coviello, 2015; Knight and Cavusgil, 1996; Oviatt and McDougall, 1994). Many articles (34) have not reported the information regarding the entry mode. From those that reported the mode of entry, most cases enter via exportation. The lack of information on entry mode keeps us from assessing the company's level of commitment when internationalize, implicating whether those cases would better fit as mMNEs (Dimitratos et al., 2003). Recent research has suggested that INV from emerging countries opts for internet-based businesses to reduce transaction costs and accelerate the internationalization process (McCormick \& Somaya, 2020). Such findings demonstrate the importance of thoroughly assessing aspects such as location and entry mode.

Finally, another relevant criterion not informed is the percentage of sales. We noticed 64 articles do not provide this information. INVS' internationalization intensity is usually assessed based on this information (Coviello, 2015). It is also one of the criteria to determine whether the company is a born global firm (Oviatt \& McDougall, 1994).
Although most articles describe their data collection, data analysis, and the procedures employed to guarantee validity and reliability, the disregard to the INVs characteristic still has methodological implications. Single case studies rely on in-depth analysis of the cases (Yin, 2009); meanwhile, multiple case studies are based on similarities and differences so patterns can emerge (Eisenhardt, 1989). Articles that do not provide companies' characteristics keep us from adequately comparing cases and findings. It also opens up space for questioning the internal and external validity of their results. Such practice raises theoretical sampling issues (Eisenhardt, 1989) and lessens the research's replication and theoretical generalization power.

Our analysis shows a balance between the focus on studies about the Internationalization Process (42) and aspects motivating or facilitating the process (57). This balance demonstrates the progress of the theory related to previous research that focuses only on the initial stages of INV's development (Aspelund, Azari, Aglen, \& Graff, 2018; Melén \& Nordman, 2007). The list with all journals is depicted in appendix A.

\section{Results}

From our analysis, the research on INVs can be comprised of five broad themes: (1) rapid internationalization process; (2) enabler of rapid internationalization; (3) entrepreneurial aspects; (4) network; and (5) growth and survival. A summary of the categories is depicted in Table 3. 
Table 3 - Category from case analysis

\begin{tabular}{|c|c|c|c|c|}
\hline Category from cases & Articles (n) & Period & Comment & Examples \\
\hline $\begin{array}{l}\text { Rapid Internationalization } \\
\text { Process }\end{array}$ & 20 & $2005-2019$ & $\begin{array}{l}\text { Understanding of the firm's rapid internationalization process } \\
\text {, before, during and after internationalization }\end{array}$ & $\begin{array}{l}\text { Glavas \& Mathews } \\
\text { Laurell et al. (2013) } \\
\text { Oyson (2020) }\end{array}$ \\
\hline Growth and Survivor & 21 & $2011-2020$ & $\begin{array}{l}\text { Understanding post-internationalization and explaining } \\
\text { international growth and expansion motives }\end{array}$ & $\begin{array}{l}\text { Schweizer } \\
\text { Kumar \& Yakhlef (2015) } \\
\text { Andersson et al. (2020) } \\
\end{array}$ \\
\hline $\begin{array}{l}\text { Enabler of Rapid } \\
\text { Internationalization }\end{array}$ & 20 & $2005-2019$ & $\begin{array}{l}\text { Understanding the fundamental mechanisms for rapid } \\
\text { internationalization }\end{array}$ & $\begin{array}{l}\text { Mainela et al. (2011) } \\
\text { Huang \& Hsieh (2013) } \\
\text { Sinkovics et al. (2018) } \\
\end{array}$ \\
\hline Entreprenurial Aspects & 13 & $2006-2018$ & $\begin{array}{l}\text { Understanding how the characteristics of the entrepreneur } \\
\text { affect the process of rapid internationalization, before, during } \\
\text { and after internationalization }\end{array}$ & $\begin{array}{l}\text { Andersson \& Evangelista (2006) } \\
\text { Yan \& Panteli (2011) } \\
\text { Arte (2017) }\end{array}$ \\
\hline Network & 23 & $2005-2019$ & $\begin{array}{l}\text { Understanding the role of networks in the } \\
\text { internationalization process, as a lever or limiter of the } \\
\text { process }\end{array}$ & $\begin{array}{l}\text { Mort \& Weerawardena (2006) } \\
\text { Vissak \& Zhang (2016) } \\
\text { Rosenbaum (2017) }\end{array}$ \\
\hline
\end{tabular}




\section{Rapid internationalization process}

Research in this category delves into understanding the whole process of internationalization, not focusing on a specific phase. Scholars have suggested the rapid internationalization is a non-linear process (Vissak \& Zhang, 2014). This process emerges from the coevolution of internationalization activities, organizational resources, and industry influences (Pajunen \& Maunula, 2008). It starts with an opportunity search, a phase in which the advantage to internationalize is constructed (Kirwan, Ratinho, van der Sijde, \& Groen, 2019). Although the literature is mainly focused on successful cases, studies indicate companies face several challenges which can constrain their internationalization process. Home-host country culture divergence, institutional systems (Prystupa-Rządca, Lupina-Wegener, \& Johannot, 2019; Zhang \& Dodgson, 2007) industry-specific context (Laurell, 2018; Su, 2013) are some of the examples.

For instance, through a longitudinal in-depth single case study, Laurell (2018) compared the medical-tech company's internalization process to three developed countries. She found the institutional, cultural, and industry differences affecting both sales and patterns of the internationalization process. Such aspect is particularly important for INV because they heavily rely on alliances (Calvo \& Villarreal, 2019) and partnerships (Rastrollo-Horrillo \& Martín-Armario, 2019) throughout the process of internationalization. Understanding the host country's overall context is critical to align their business model with that from partners in the target market (Sainio et al., 2011).

\section{Enablers of rapid internationalization}

Several authors have been interested in understanding what enables small companies to internationalize rapidly. Since the beginning of studies on international new ventures, technology has been one of the main aspects that facilitate the entry of those companies in several markets in an accelerated way (Arenius et al., 2005; Gabrielsson \& Gabrielsson, 2011). As new studies have been developed, other aspects have emerged as relevant for these companies to internationalize quickly. For instance, the founders' ability to lead the internationalization process (Hashim, 2013; Sekliuckiene, 2017), the ownership structure of the company (Elo, 2016), foreign market knowledge (Huang \& Hsieh, 2013), and market access (Coelho, de Mello, \& da Rocha, 2014) are few enablers reported in the literature.

The aggregated knowledge from these studies indicates that these aspects are necessary but not enough to enable the internationalization process. For example, access to new markets may depend on the local and international networks in which the company operates (Vissak, 2013) and the forged strategic alliances (Calvo \& Villarreal, 2019; Franco \& Haase, 2016). Langseth and colleagues (2016) have found the internationalization speed relies on four forces: technology, entrepreneur perceptions, foreign market knowledge, and tie strength in networks. In turn, organizations must develop capabilities to access several networks, such as internal problem solving, external solution creation, opportunity selling, and opportunity organizing (Mainela, Pernu, \& Puhakka, 2011).

A relevant feature of international new ventures is the scarcity of resources which can constrain their internationalization process. Thus, developing efficient business models is pressing for those firms (Kraus, Brem, Schuessler, Schuessler, \& Niemand, 2017). Additionally, to enable rapid internationalization, international new ventures need to orchestrate a series of internal and external resources and capabilities that foster innovation, the development of managerial skills, and access to networks (Hermel \& Khayat, 2011; Laudien \& Daxböck, 2017). For instance, Laudien and Daxböck (2017) found that firms have overcome resource constraints through service-oriented capability, allowing them to use cooperative entry modes to compensate for the lack of market knowledge.

\section{Entrepreneur Aspect}

Another aspect arising from our analysis is those related to the entrepreneur. Studies in this realm deal with the entrepreneur's role at each stage of the internationalization process. The entrepreneur's analysis shows us that the search 
process for new markets is very close to the effectuation process. It unifies the theories of entrepreneurship and international business (da Rocha, Simões, de Mello, \& Carneiro, 2017). Characteristics of willingness to experiment are closely linked to the controlled risk-taking entry mode (Karra et al., 2016). One of the most critical entrepreneurs' aspects in the INVS internationalization process is their openness to learning about the foreign market (Voudouris, Dimitratos, \& Salavou, 2011). Developing human capital management can guide employees to deal with a diverse customer profile (Kungwansupaphan \& Siengthai, 2014). Both aspects can prevent the company from failing in this process (Nummela, Saarenketo, \& Loane, 2016).

\section{Network}

The networks have an essential role in the firms' rapid internationalization process. Scholars have noticed networks support firms internationalization in two specific moments. Exclusively at the beginning of the internationalization process as an enabler. And throughout the process, because they remain relevant in the growth and survival phases (Andersson, Evers, \& Gliga, 2018; de Mello, da Rocha, \& da Silva, 2019).

Networks play a fundamental role in most of the cases studied. They can be the source of opportunities for international expansion by accelerating the process (Laurell, 2018) and impelling the company through contacts in the foreign country, and promoting foreign integration (Vasilchenko \& Morrish, 2011). In the development of the business, networks have the role of facilitating foreign market knowledge acquisition. It can also improve the organization's human capital (Lindstrand, Melén, \& Nordman, 2011) and fill the resource gap providing access to social capital and generating skills in the startup of the business ( Coviello and Cox, 2007).

\section{Growth and Survivor}

Growth and Survivor have tardily emerged as a relevant topic in the INVs literature. Studies that address this stage of the process were published from 2011 forward. The focus on the initial phases of rapid internationalization before 2011 is natural since they are the theoretical intersection between entrepreneurship and international business (Zahra, 2005). Because INVs challenge the mainstream of both theory streams understanding the growth and survival phase became essential to the theory evolution (Khan \& Lew, 2018).

Scholars have suggested INVs seek legitimacy after stabilizing in the foreign market to pursue growth and survival (Turcan, 2011, 2012). To keep growing and expanding in the foreign market, INV needs to adapt its resources and capabilities (Evers, 2011). Some cases require reconfiguring the organization in terms of your capabilities (Hagen \& Zucchella, 2014). Some factors appear to limit the growth and survival of the firm. For instance, the relationship with customers in the foreign country can require specific capabilities that are different from those needed for the local market ( Kumar and Yakhlef, 2014). To support their growth phase, firms should create a culture that boosts value creation for customers in the foreign market. They also need to combine proactive and reactive market orientation to create and deliver such value (Andersson, Awuah, Aagerup, \& Wictor, 2020). Growth and survival also rely on the entrepreneur's ability to lead and offer clear goals to their team (Khan \& Lew, 2018; Rastrollo-Horrillo \& Martín-Armario, 2019). 
Moving Research on International new Ventures Forward: A Systematic Reviews on Case Studies

\section{Moving forward: a future research agenda}

To explore possible ways to build and strengthen the theory of INVs, we discuss our findings and offer paths for future agenda. We focus on two mains aspects, the operationalization of the concepts and the implications for INVs theory building and the evolution of international new venture phenomena.

\section{Conceptualization stretching and theoretical implications}

Soon after introducing the international new venture concept (McDougall, 1989; Oviatt \& McDougall, 1994), others have emerged (e.g., BG, Global startup, and mMNE) to explain similar phenomena, however with relevant differences among them (see figure 1). Despite the recurrent calls on the literature (Coviello, McDougall, and Oviatt, 2011; Nicole Coviello, 2015; Welch et al., 2016), researchers still using the concepts interchangeably (e.g., INVs and BG) or stretching criteria without discussing the implications. For instance, studies have used the concept of "born global" with no consideration for the inception nor the intensity of internationalization (e.g., Calvo \& Villarreal, 2019). Both characteristics implicate the correct assessment of the firms' capacity to rapidly orchestrate resources and develop networks to internationalize and grow in the international market. Future studies should carefully report the cases' characteristics and avoid conceptsstretching without considering and discussing the implications.

INV are small companies with scarce resources and highly dependable on the entrepreneur's capabilities (Bangara, Freeman, \& Schroder, 2012; Kraus et al., 2017; Oviatt \& McDougall, 1994). These aspects can implicate, for example, the level of risk they might take abroad (Karra et al., 2016), on the intensity of their internationalization (Weerawardena, Mort, Salunke, Knight, \& Liesch, 2014), and on the role networks will play on their internationalization process (Coviello and Cox, 2007). Thus, spin-off companies (e.g., Huang \& Hsieh, 2013), companies with a structure such as franchising (e.g., Frazer \& Merrilees, 2012), and cooperatives (e.g., Elo, 2016) carry characteristics that are fundamentally different from the INVs. These companies will usually have access to more resources and capabilities previously to the initial phase of internationalization. The founders' role can be increasingly diminished, which can influence their internationalization process, and they might have faster and easier access to international networks. Future studies should reflect on the specific characteristics of company's they select. Solely focusing on one criterion, such as whether the company internationalized within three years from inception, is not enough.

Future studies should also consider aspects such as sources of financing and ownership structure when theorizing about INVs. Our suggestion is not to limit them to "what is and what is not" an INV but to discuss the implication when adding or dropping criteria. Future studies could empirically test those criteria, especially in light of the emergence of the new breeds of companies that rapidly internationalize and grow, such as the unicorn companies. Future studies can investigate the critical differences between INV and Unicorns that internationalize (Jinzhi \& Carrick, 2019).

Moreover, with the technological advancement and increasing number of platformbased firms, companies can easily access several international markets with little commitment. If future studies closely regard the characteristics that differ INVs, several venues can be explored. For instance, which kind of INV would those companies fit in? Are those companies present in enough countries to be a global startup, or should they be considered a born global company due to their exporting focus? How committed are those companies in the international market? Recent literature shows that platform-based firms have limitations and risks sometimes forgotten (Jean et al., 2020); which are related to the internationalization process? Those questions can provide venues for theory development through case studies.

Building theory through case studies requires caution on the case selection criteria (Eisenhardt, 1989; Stake, 1998; Yin, 2009). The cases' characteristics are the base from which research induces from the empirical setting to theorization. That is especially true in multiple cases that require a systematic comparison among the cases so that conclusions can be drawn (Eisenhardt, 1989). The fact that several articles did not report 
basic information about the cases can challenge the theory advancement through case studies. Those studies can be questioned regarding their internal validity. Without the explicit limitation of the cases, it is difficult to characterize them as INV (BG, mMNEs, or Global startup). They also fall short in external validity since the replication of case studies or even the theoretical generalization is compromised due to the lack of basis for comparability.

Finally, the cases we reviewed still focusing on born global and INVs, with little attention to mMNE. Only three articles analyzed mMNE. Two of them characterized the cases reporting internationalization pace and the commitment expansion through Foreign Direct Investment (FDI) strategy (Hermel \& Khayat, 2011; Sinkovics, Hoque, \& Sinkovics, 2018; Vanninen, Kuivalainen, \& Ciravegna, 2017). Future studies should draw on those to extend the theorization on mMNEs. Amongst our sample, no articles have analyzed Global-startups. Future studies could be less prone to stretch BG and INVs concepts if considering these types of firms. That would open up the path to developing the INVs theory even further by grasping the particularity of each kind of INVs.

\section{The INVs theory evolution}

The categories that emerged from the case study show us an interconnection between them and the INV literature. The balance on the number of articles we found on the internationalization process and growth and survival demonstrate the theory is evolving. The studies that deal with rapid internationalization started in 2005 (Rialp, Rialp, Urbano, \& Vaillant, 2005), close to publishing seminal studies such as (Knight \& Cavusgil, 2004). Because of the incipience of the phenomena, those studies were focused on the initial phases of the internationalization process. They marked the beginning of a research area in the intersection of Entrepreneurship and International Business - the International Entrepreneurship stream ( McDougall, 1989; McDougall, Shane, and Oviatt, 1994; Verbeke and Ciravegna, 2018). After 2010 we notice the emergence of studies focused on understanding the growth process of these companies (Gerschewski, Lew, Khan, \& Park, 2018; Khan \& Lew, 2018; Lin \& Si, 2019). Evers (2011) observed aspects such as capabilities, legitimacy, the importance of knowledge, and the limitations in this phase. This movement seems to be a natural evolution towards field maturity.

The categories that emerged also show that researchers have been working to understand the personal and organizational aspects that enable rapid internationalization and growth. A point of convergence in the analysis of the three categories of aspects (e.g., Enabler of rapid internationalization, Entrepreneurial aspects, and Network) is their relationship with knowledge about the host market (Altshuler \& Tarnovskaya, 2010). In the international pre-internationalization phase, this knowledge is demonstrated by the managers' experience; after the entry into a foreign market, knowledge serves as a lever in the searching for legitimation and growth (Andersson \& Evangelista, 2006). Entrepreneur characteristics, such as leadership capability, stand out (Chhotray, Sivertsson, and Tell, 2018). The absence of those aspects can lead some companies to fail in the internationalization process (Kungwansupaphan \& Siengthai, 2014). Knight \& Cavusgil (2004) highlighted the role of market knowledge, and it has been reinforced by Coviello (2015).

The crescent numbers of research about the growth phase show the next step for theory building. Following Paul and Rosado-Serrano (2019), we suggest future studies exploring different theoretical lenses to understand the growth phase better. Future studies can use the business model concept to capture the value creation mechanism in the host country (Teece, 2010) and test whether the validation process would be similar in the home and host country (Bortolini, Nogueira Cortimiglia, Danilevicz, \& Ghezzi, 2018).

The INV literature reaches a point of maturity that allows researchers to test the variables generated from the cases quantitatively. For instance, future studies can use Structural Equation Modelling factor analysis to verify the influence of networks and entrepreneurs in the whole internationalization process, thus measuring their impact at each stage. An aspect that has been analyzed by the cases separately but that needs to be compared is the difference between the effect of government internationalization programs versus the private 
and academic accelerations. Both change the aspects of rapid internationalization, and today there is already sufficient theoretical foundation for these tests. Therefore, future studies could delve into the differences and similarities among the possible acceleration incentives (e.g., public, private, academic). It would also be relevant to assess the influence of those incentives in each phase of the internationalization process.

The recent COVID-19 pandemic changes all social and economic global scenario (Zahra, 2021) generating initiatives like "The great reset" (World

\section{Conclusions}

This paper offers a systematized analysis of 99 articles that summed 473 case studies regarding INVs. We integrated the knowledge developed through empirical research and opened venues to further develop the INVs theory. We also grasped conceptual issues related to the use of INV's, as it is still broad and inconsistent throughout the literature analyzed. We contribute to the INV's literature by demonstrating the theory is now evolving to understand the postinternationalization moment of these companies (e.g., how they grow and survive in the international market). Studies also suggest that network and entrepreneurial aspects are essential in the initial phase of internationalization, but their relevance remains high in its growth process.

\section{References}

Altshuler, L., \& Tarnovskaya, V. V. (2010). Branding capability of technology born globals. Journal of Brand Management, 18(3), 212-227. https://doi.org/10.1057/bm.2010.47

Andersson, S., Awuah, G. B., Aagerup, U., \& Wictor, I. (2020). How do mature born globals create customer value to achieve international growth? International Marketing Review, 37(2), 185-211. https://doi.org/10.1108/IMR-11-2018-0340

Andersson, S., \& Evangelista, F. (2006). The entrepreneur in the Born Global firm in Australia and Sweden. Journal of Small Business and Enterprise Development, 13(4), 642-659. https://doi.org/10.1108/14626000610705796
Economic Forum, 2021), that include a change in "the nature of business models and the management of a global commons" (World Economic Forum, 2021). Such movement can directly impact the INVs phenomena. Future studies can set off to investigate what barriers INV will fight against in this new scenario? To which degree the sanitary barriers will slow down the internationalization process of INVs? What is the effect of the great reset in INV financing? The response to all these questions could help to push the discussion on INVs further.

We also demonstrate that despite scholars' call for careful consideration of INVS' concepts operationalization, studies still add and drop criteria without discussing the implications to the theory. We discuss those implications, and we offer a set of insights for future studies to advance the knowledge on INVs. Moreover, to the extent of our knowledge, there is no recent review on INVs that analyzes case studies from several management fields. Our research does not go without limitation. The categories and results we drew from are limited to the case study methods' possibilities and the authors' interpretation. Although they allow theoretical generalization (Eisenhardt, 1989), researchers should do so cautiously, considering the particularity of each case.

Andersson, S., Evers, N., \& Gliga, G. (2018). Entrepreneurial marketing and born global internationalisation in China. Qualitative Market Research, 21(2), 202-231. https://doi.org/10.1108/QMR-11-2016-0115

Arenius, P., Sasi, V., \& Gabrielsson, M. (2005). Rapid internationalisation enabled by the Internet: The case of a knowledge intensive company. Journal

of International Entrepreneurship, 3(4), 279-290. https://doi.org/10.1007/s10843-006-7856-x

Aspelund, A., Azari, M. J., Aglen, A. F., \& Graff, S. G. (2018). The birth and development of a born global industry: The case of microelectronics in Norway. Journal of International Entrepreneurship, 16(1), 82-108. https://doi.org/10.1007/s10843017-0206-3 
Bader, A., \& Mazzarola, T. (2009). Defining the Born Global Firms: A Review of the Literature. Australian and New Zealand Academy of Management. Managing in the Pacific Century, 24th Annual ANZAM Conference.

Bangara, A., Freeman, S., \& Schroder, W. (2012). Legitimacy and accelerated internationalisation: An Indian perspective. Journal of World Business, 47(4), 623-634.

https://doi.org/10.1016/j.jwb.2011.09.002

Bell, J., McNaughton, R., Young, S., \& Crick, D. (2003). Towards an integrative model of small firm internationalisation. Journal of International Entrepreneurship, 1(4), 339-362.

Bortolini, R. F., Nogueira Cortimiglia, M., Danilevicz, A. de M. F., \& Ghezzi, A. (2018). Lean startup: a comprehensive historical review. Management Decision, ahead-of-p(ahead-of-print). https://doi.org/10.1108/MD-07-2017-0663

Braun, V., \& Clarke, V. (2006). Using thematic analysis in psychology. In Qualitative Research in Psychology2. Routledge.

Brouthers, K. D., Geisser, K. D., \& Rothlauf, F. (2016). Explaining the internationalization of ibusiness firms. Journal of International Business Studies, 47(5), 513-534. https://doi.org/10.1057/jibs.2015.20

Calvo, N., \& Villarreal, O. (2019). Internationalization as process of value distribution through innovation: polyhedral diagnosis of a "born global" firm. Journal of Business and Industrial Marketing, 34(3), 561-574. https://doi.org/10.1108/JBIM-03-2017-0060

Cannone, G., Pisoni, A., \& Onetti, A. (2014). Born global companies founded by young entrepreneurs. A multiple case study. International Journal of Entrepreneurship and Innovation Management, 18(2-3), 210-232. https://doi.org/10.1504/IJEIM.2014.062875

Cavusgil, S. T., \& Knight, G. (2015). The born global firm: An entrepreneurial and capabilities perspective on early and rapid internationalization. Journal of International Business Studies, 46(1), 316. https://doi.org/10.1057/jibs.2014.62
Coelho, B. V., de Mello, R. C., \& da Rocha, A. (2014). Leblon Cachaça: A born global in a traditional industry. Journal of Business Research, 67(4),

567-575.

https://doi.org/10.1016/j.jbusres.2013.11.017

Corbin, J., \& Strauss, A. (2008). Strategies for Qualitative Data Analysis. In Basics of Qualitative Research (3rd ed.). Sage Publications.

Coviello, N. (2015). Re-thinking research on born globals. Journal of International Business Studies, 46(1), 17-26 https://doi.org/10.1057/jibs.2014.59

Coviello, N. E., \& Cox, M. P. (2007). The resource dynamics of international new venture networks. Journal of International Entrepreneurship, 4(2-3), 113-132. https://doi.org/10.1007/s10843-007-0004-4

Coviello, N. E., McDougall, P. P., \& Oviatt, B. M. (2011). The emergence, advance and future of international entrepreneurship research - An introduction to the special forum. Journal of Business Venturing, 26(6), 625-631. https://doi.org/10.1016/j.jbusvent.2011.07.002

Crossan, M. M., \& Apaydin, M. (2010). A multidimensional framework of organizational innovation: A systematic review of the literature. Journal of Management Studies, 47(6), 1154-1191. https://doi.org/10.1111/j.1467-

6486.2009.00880.x

da Rocha, A., Simões, V. C., de Mello, R. C., \& Carneiro, J. (2017). From global startups to the borderless firm: Why and how to build a worldwide value system. Journal of International Entrepreneurship, 15(2), 121-144. https://doi.org/10.1007/s10843-017-0200-9

de Mello, R. C., da Rocha, A., \& da Silva, J. F. (2019). The long-term trajectory of international new ventures: A longitudinal study of software developers. Journal of International Entrepreneurship, 17(2), 144-171. https://doi.org/10.1007/s10843-018-0236-5

DeSantis, L., \& Ugarriza, D. N. (2000). The concept of theme as used in qualitative nursing research. Western Journal of Nursing Research, 22(3), 351-372. 
Dib, L. A., da Rocha, A., \& da Silva, J. F. (2010). The internationalization process of Brazilian software firms and the born global phenomenon: Examining firm, network, and entrepreneur variables. Journal of International Entrepreneurship, 8(3), 233-253. https://doi.org/10.1007/s10843-010-0044-z

Dimitratos, P., Johnson, J., Slow, J., \& Young, S. (2003). Micromultinationals: European Management Journal, 21(2), 164-174. https://doi.org/10.1016/S0263-2373(03)00011-2

Dyer, W. G., \& Wilkins, A. L. (1991). Better Stories, Not Better Constructs, to Generate Better Theory: A Rejoinder to Eisenhardt. The Academy of Management Review, 16(3), 613. https://doi.org/10.2307/258920

Dzikowski, P. (2018). A bibliometric analysis of born global firms. Journal of Business Research, 85(December 2017), 281-294. https://doi.org/10.1016/j.jbusres.2017.12.054

Edmondson, A. C., \& Mcmanus, S. E. (2007). Methodological fit in management field research. Academy of Management Review, 32(4), 12461264. https://doi.org/10.5465/amr.2007.26586086

Eisenhardt, K. M. (1989). Building Theories from Case Study Research. Academy of Management Review, 14(4), 532-550. https://doi.org/10.5465/amr.1989.4308385

Elo, M. (2016). Can a startup establish international industry standards? The international development of a data solution platform in car parts business. International Journal of Foresight and Innovation Policy, 11(4), 256. https://doi.org/10.1504/IJFIP.2016.084531

Evers, N. (2011). International new ventures in "low tech" sectors: A dynamic capabilities perspective. Journal of Small Business and Enterprise Development, 18(3), 502-528. https://doi.org/10.1108/14626001111155682

Franco, M., \& Haase, H. (2016). Internationalisation of born globals: The role of strategic alliances. European Journal of International Management, 10(2), 181-201. https://doi.org/10.1504/EJIM.2016.074471
Frazer, L., \& Merrilees, B. (2012). Pioneering Asian Franchise Brands: Pho24 in Vietnam. Journal of Marketing Channels, 19(4), 295-309. https://doi.org/10.1080/1046669X.2012.700264

Freeman, S., Edwards, R., \& Schroder, B. (2006). How Smaller Born-Global Firms Use Networks and Alliances to Overcome Constraints to Rapid Internationalization. Journal of International Marketing, 14(3), 33-63. https://doi.org/10.1509/jimk.14.3.33

Gabrielsson, M., \& Gabrielsson, P. (2011). Internet-based sales channel strategies of born global firms. International Business Review, 20(1), 88-99.

https://doi.org/10.1016/j.ibusrev.2010.05.001

Gabrielsson, M., Gabrielsson, P., \& Dimitratos, P. (2014). International Entrepreneurial Culture and Growth of International New Ventures. Management International Review, 54(4), 445-471. https://doi.org/10.1007/s11575-014-0213-8

Gabrielsson, M., Sasi, V., \& Darling, J. (2004). Finance strategies of rapidly-growing Finnish SMEs: Born Internationals and Born Globals. European Business Review, 16(6), 590-604. https://doi.org/10.1108/09555340410565413

Gerschewski, S., Lew, Y. K., Khan, Z., \& Park, B. II. (2018). Post-entry performance of international new ventures: The mediating role of learning orientation. International Small Business Journal: Researching Entrepreneurship, 36(7), 807-828. https://doi.org/10.1177/0266242618790321

Glaser, B., \& Strauss, A. (1967). The discovery of grounded theory: strategies of qualitative research. London: Weidenfeld and Nicholson.

Guo, B., \& Wang, Z. (2020). Internationalisation path heterogeneity and growth for international new ventures. International Small Business Journal: Researching Entrepreneurship, 026624262096579. https://doi.org/10.1177/0266242620965792

Hagen, B., \& Zucchella, A. (2014). Born Global or Born to Run? The Long-Term Growth of Born Global Firms. Management International Review, 54(4), 497-525. https://doi.org/10.1007/s11575-014 0214-7 
Hashai, N., \& Almor, T. (2004). Gradually internationalizing 'born global' firms: an oxymoron? International Business Review, 13(4), 465-483. https://doi.org/10.1016/j.ibusrev.2004.04.004

Hashim, F. (2013). Early internationalisation of emerging MNEs: Case of Top Glove Malaysia. Journal for Global Business Advancement, 6(2), 120-137. https://doi.org/10.1504/JGBA.2013.053560

Hermel, P., \& Khayat, I. (2011). The role of resources: micro-firms internationalization in the French context. Journal of Small Business and Enterprise Development, 18(2), 298-310. https://doi.org/10.1108/14626001111127089

Hohenthal, J. (2006). Integrating qualitative and quantitative methods in research on international entrepreneurship. Journal of International Entrepreneurship, 4(4), 175-190. https://doi.org/10.1007/s10843-007-0010-6

Huang, H. Y., \& Hsieh, M. H. (2013). The accelerated internationalization of born global firms: a knowledge transformation process view. Journal of Asia Business Studies.

Ibeh, K., Jones, M. V., \& Kuivalainen, O. (2018). Consolidating and advancing knowledge on the postentry performance of international new ventures. International Small Business Journal: Researching Entrepreneurship, 36(7), 741-757. https://doi.org/10.1177/0266242618793926

Jean, R.-J. "Bryan," Kim, D., \& Cavusgil, E. (2020). Antecedents and outcomes of digital platform risk for international new ventures' internationalization. Journal of World Business, 55(1), 101021. https://doi.org/10.1016/j.jwb.2019.101021

Jiang, G., Kotabe, M., Zhang, F., Hao, A. W., Paul, J., \& Wang, C. L. (2020). The determinants and performance of early internationalizing firms: A literature review and research agenda. International Business Review, 29(4), 101662. https://doi.org/10.1016/j.ibusrev.2019.101662

Jinzhi, Z., \& Carrick, J. (2019). The Rise of the Chinese Unicorn: An Exploratory Study of Unicorn Companies in China. Emerging Markets Finance and Trade, 55(15), 3371-3385. https://doi.org/10.1080/1540496X.2019.1610877
Johanson, J., \& Vahlne, J.-E. (1977). The Internationalization Process of the Firm - A Model of Knowledge Development and Increasing Foreign Market Commitments. Journal of International Business Studies, 8(1), 23-32. https://doi.org/10.1057/palgrave.jibs.8490676

Jones, M. V, Coviello, N., \& Tang, Y. K. (2011). International Entrepreneurship research (19892009): A domain ontology and thematic analysis. Journal of Business Venturing, 26(6), 632-659. https://doi.org/10.1016/j.jbusvent.2011.04.001

Karra, N., Phillips, N., Tracey, P., Jurcan, R. V., Mäkelä, M. M., Sørensen, O. J., ... Freeman, S. (2016). Using Case Research to Reconstruct Concepts: A Methodology and Illustration. International Business Review, 54(4), 297-310. https://doi.org/10.1016/j.jwb.2012.09.003

Khan, Z., \& Lew, Y. K. (2018). Post-entry survival of developing economy international new ventures: A dynamic capability perspective. International Business Review, 27(1), 149-160. https://doi.org/10.1016/j.ibusrev.2017.06.001

Kirwan, P., Ratinho, T., van der Sijde, P., \& Groen, A. J. (2019). The early development of International New Ventures: a multidimensional exploration. International Journal of Entrepreneurial Behaviour and Research, 25(6) 1340-1367. https://doi.org/10.1108/IJEBR-122017-0508

Knight, G. A., \& Cavusgil, S. T. (1996). The born global firm: A challenge to traditional internationalization theory. Advances in International Marketing, 8, 11-26.

Knight, G. A., \& Cavusgil, S. T. (2004). Innovation, organizational capabilities, and the born-global firm. Journal of International Business Studies, 35(2), 124-141. https://doi.org/10.1057/palgrave.jibs.8400071

Kontinen, T., \& Ojala, A. (2011). Network ties in the international opportunity recognition of family SMEs. International Business Review, 20(4), 440453.

https://doi.org/10.1016/j.ibusrev.2010.08.002 
Kraus, S., Brem, A., Schuessler, M., Schuessler, F., \& Niemand, T. (2017). Innovative Born Globals: Investigating The Influence Of Their Business Models On International Performance. International Journal of Innovation Management, 21(1). https://doi.org/10.1142/S1363919617500050

Kumar, N., \& Yakhlef, A. (2014). How capabilities evolve in a born global firm? Journal of Entrepreneurship in Emerging Economies, 6(3), 223242. https://doi.org/10.1108/JEEE-06-2014-0018

Kungwansupaphan, C., \& Siengthai, S. (2014). Exploring entrepreneurs' human capital components and effects on learning orientation in early internationalizing firms. International Entrepreneurship and Management Journal, 10(3), 561-587. https://doi.org/10.1007/s11365-0120237-0

Langseth, H., O'Dwyer, M., \& Arpa, C. (2016). Forces influencing the speed of internationalisation. Journal of Small Business and Enterprise Development, 23(1), 122-148. https://doi.org/10.1108/JSBED-10-2013-0155

Laudien, S. M., \& Daxböck, B. (2017). Enhancing the understanding of international new ventures: a service-oriented perspective. Management Research Review, 40(5), 494-516. https://doi.org/10.1108/MRR-07-2015-0169

Laurell, H. (2018). An international new venture's commercialization of a medical technology innovation: The role of institutional healthcare settings. International Marketing Review, 35(1), 136-163. https://doi.org/10.1108/IMR-04-20150112

Lin, S., \& Si, S. (2019). The influence of exploration and exploitation on born globals' speed of internationalization. Management Decision, 57(1), 193-210. https://doi.org/10.1108/MD-082017-0735

Lindstrand, A., Melén, S., \& Nordman, E. R. (2011). Turning social capital into business: A study of the internationalization of biotech SMEs. International Business Review, 20(2), 194-212. https://doi.org/10.1016/j.ibusrev.2011.01.002
Mainela, T., Pernu, E., \& Puhakka, V. (2011). The development of a high-tech international new venture as a process of acting. Journal of Small Business and Enterprise Development, 18(3), 430456.

https://doi.org/10.1108/14626001111155655

Mainela, T., Puhakka, V., \& Servais, P. (2014). The Concept of International Opportunity in International Entrepreneurship: A Review and a Research Agenda. International Journal of Management Reviews, 16(1), 105-129. https://doi.org/10.1111/ijmr.12011

Mathews, J. A. (2006). Dragon multinationals: New players in 21st century globalization. Asia Pacific Journal of Management, 23(1), 5-27. https://doi.org/10.1007/s10490-006-6113-0

Mathews, J. A., \& Zander, I. (2007). The international entrepreneurial dynamics of accelerated internationalisation. Journal of International Business Studies, 38(3), 387-403. https://doi.org/10.1057/palgrave.jibs.8400271

McCormick, M., \& Somaya, D. (2020). Born globals from emerging economies: Reconciling early exporting with theories of internationalization. Global Strategy Journal, 10(2), 251-281. https://doi.org/10.1002/gsj.1368

McDougall, P., Shane, S., \& Oviatt, B. M. (1994). Explaining the formation of international new ventures: The limits of theories from international business research. Journal of Business Venturing, 9(6), 469-487. https://doi.org/10.1016/0883 9026(94)90017-5

McDougall, Patricia P. (1989). International versus domestic entrepreneurship: New venture strategic behavior and industry structure. Journal of Business Venturing, 4(6), 387-400. https://doi.org/10.1016/0883-9026(89)90009-8

McDougall, Patricia Pshillips, Shane, S., \& Oviatt, B. M. (1994). Explaining the formation of international new ventures: The limits of theories from international business research. Journal of Business Venturing, 9(6), 469-487. https://doi.org/10.1016/0883-9026(94)90017-5 
Melén, S., \& Nordman, E. R. (2007). The value of human capital for the networks of born globals. International Journal of Globalisation and Small Business, 2(2), 205-219. https://doi.org/10.1504/JJGSB.2007.015482

Miles, M. ., Huberman, M. A., \& Saldana, J. (2014). Drawing and verifying conclusions. Qualitative data analysis: A methods sourcebook, (3rd, ed.). Sage Publications.

Moen, $\varnothing$. (2002). The Born Globals. International Marketing Review, 19(2), 156-175. https://doi.org/10.1108/02651330210425015

Mort, G. S., \& Weerawardena, J. (2006) Networking capability and international entrepreneurship: How networks function in Australian born global firms. International Marketing Review, 23(5), 549-572. https://doi.org/10.1108/02651330610703445

Nardali, S. (2017). Global Doğan Firmalar Üzerine Sistematik Literatür İncelemesi. Yönetim ve Ekonomi: Celal Bayar Üniversitesi iktisadi ve Idari Bilimler Fakültesi Dergisi, 563-578. https://doi.org/10.18657/yonveek.335267

Nummela, N., Saarenketo, S., \& Loane, S. (2016). The dynamics of failure in international new ventures: A case study of Finnish and Irish software companies. International Small Business Journal, 34(1), 51-69. https://doi.org/10.1177/0266242614539363

Oviatt, B. M., \& McDougall, P. P. (1994). Toward a Theory of International New ventures. Journal of International Business Studies, 25(1), 45-64. https://doi.org/10.1057/palgrave.jibs.8490193

Oviatt, B. M., \& McDougall, P. P. (2005). Defining International Entrepreneurship and Modeling the Speed of Internationalization. Entrepreneurship Theory and Practice, 29(5), 537-553. https://doi.org/10.1111/j.1540-6520.2005.00097.x

Øyna, S., \& Alon, I. (2018). A Review of Born globals. International Studies of Management and Organization, 48(2), 157-180. https://doi.org/10.1080/00208825.2018.1443737

Pajunen, K., \& Maunula, M. (2008). Internationalisation: A co-evolutionary perspective. Scandinavian Journal of Management, 24(3), 247258. https://doi.org/10.1016/j.scaman.2008.02.001
Paul, J., \& Rosado-Serrano, A. (2019). Gradual Internationalization vs Born-Global/International new venture models: A review and research agenda. International Marketing Review, 36(6), 830-858. https://doi.org/10.1108/IMR-10-2018-0280

Pettersen, I. B., \& Tobiassen, A. E. (2012). Are born globals really born globals? The case of academic spin-offs with long development periods. Journal of International Entrepreneurship, 10(2), 117-141. https://doi.org/10.1007/s10843-0120086-5

Podsakoff, P. M., Mackenzie, S. B., Bachrach, D. G., \& Podsakoff, N. P. (2005). The influence of management journals in the 1980s and 1990s. Strategic Management Journal, 26(5), 473-488. https://doi.org/10.1002/smj.454

Prystupa-Rządca, K., Lupina-Wegener, A., \& Johannot, C. (2019). Lessons learned from Swiss born globals entering Brazil. Journal of Entrepreneurship in Emerging Economies, 12(1), 125-143. https://doi.org/10.1108/JEEE-12-20180139

Rastrollo-Horrillo, M. Á., \& Martín-Armario, J. (2019). Organisational barriers to nascent bornglobal growth: Learning from the inside. Journal of International Entrepreneurship, 17(3), 454-473. https://doi.org/10.1007/s10843-019-00256-1

Rennie, M. W. (1993). Born global. McKinsey Quarterly, 4(4), 45-52.

Reuber, A. R., Knight, G. A., Liesch, P. W., \& Zhou, L. (2018). International entrepreneurship: The pursuit of entrepreneurial opportunities across national borders. Journal of International Business Studies, 49(4), 395-406. https://doi.org/10.1057/s41267-018-0149-5

Romanello, R., \& Chiarvesio, M. (2019). Early internationalizing firms: 2004-2018. Journal of International Entrepreneurship, 17(2), 172-219. https://doi.org/10.1007/s10843-018-0241-8

Sainio, L. M., Saarenketo, S., Nummela, N., \& Eriksson, T. (2011). Value creation of an internationalizing entrepreneurial firm: The business model perspective. Journal of Small Business and Enterprise Development, 18(3), 556570.

https://doi.org/10.1108/14626001111155709 
Saldaña, J. (2013). The Coding Manual for Qualitative Researchers. In Sage Publications (Second). California: Sage Publications Ltd.

Sekliuckiene, J. (2017). Factors leading to early internationalization in emerging Central and Eastern European economies. European Business Review, 29(2), 219-242. https://doi.org/10.1108/EBR-122015-0158

Sharma, D. D., \& Blomstermo, A. (2003). The internationalization process of Born Globals: a network view. International Business Review, 12(6), 739-753.

https://doi.org/10.1016/j.ibusrev.2003.05.002

Siggelkow, N. (2007). Persuasion with Case Studies. The Academy of Management Journal, 50(1), 20-24. https://doi.org/10.2307/20159838

Sinkovics, N., Hoque, S. F., \& Sinkovics, R. R. (2018). Supplier Strategies and Routines for Capability Development: Implications for Upgrading. Journal of International Management, 24(4), 348368. https://doi.org/10.1016/j.intman.2018.04.005

Stake, R. E. (1998). Case studies. In Strategies of Qualitative Inquiry (pp. 445-454). California: Sage Publications.

Su, N. (2013). Internationalization Strategies of Chinese It Service Suppliers. MIS Quarterly, 37(1), 175-200.

https://doi.org/10.1179/1024529412Z.0000000002 3

Tawse, A., \& Tabesh, P. (2021). Strategy implementation: A review and an introductory framework. European Management Journal, 39(1), 22-33. https://doi.org/10.1016/j.emj.2020.09.005

Tranfield, D., Denyer, D., \& Smart, P. (2003). Towards a Methodology for Developing EvidenceInformed Management Knowledge by Means of Systematic Review. British Journal of Management, 14(3), 207-222. https://doi.org/10.1111/14678551.00375

Tuomisalo, T., \& Leppäaho, T. (2019). Learning in international new ventures: A systematic review. International Business Review, 28(3), 463-481. https://doi.org/10.1016/j.ibusrev.2018.11.005
Turcan, R. V. (2011). Toward a theory of international new venture survivability. Journal of International Entrepreneurship, 9(3), 213-232. https://doi.org/10.1007/s10843-011-0075-0

Turcan, R. V. (2012). External legitimation in international new ventures: Toward the typology of captivity. International Journal of Entrepreneurship and Small Business, 15(2), 262283. https://doi.org/10.1504/IJESB.2012.045207

Vanninen, H., Kuivalainen, O., \& Ciravegna, L. (2017). Rapid multinationalization: Propositions for studying born micromultinationals. International Business Review, 26(2), 365-379. https://doi.org/10.1016/j.ibusrev.2016.09.005

Vasilchenko, E., \& Morrish, S. (2011). The Role of Entrepreneurial Networks in the Exploration and Exploitation of Internationalization Opportunities by Information and Communication Technology Firms. Journal of International Marketing, 19(4), 88-105. https://doi.org/10.1509/jim.10.0134

Verbeke, A., \& Ciravegna, L. (2018). International entrepreneurship research versus international business research: A false dichotomy? Journal of International Business Studies, 49(4), 387-394. https://doi.org/10.1057/s41267-018-0154-8

Vissak, T. (2013). The emergence and success factors of fast internationalizers: Four cases from Estonia. Market Entry and Operational Decision Making in East-West Business Relationships, 9868(February), 11-34. https://doi.org/10.1300/J097v13n01_02

Vissak, T., \& Zhang, X. (2014). Chinese immigrant entrepreneurs' involvement in internationalization and innovation: Three Canadian cases. Journal of International Entrepreneurship, 12(2), 183-201. https://doi.org/10.1007/s10843-014-0128-2

Voudouris, I., Dimitratos, P., \& Salavou, H. (2011). Entrepreneurial learning in the international new high-technology venture. International Small Business Journal, 29(3), 238258.

https://doi.org/10.1177/0266242610369739 
Wadeson, N. (2020). Internationalisation theory and Born Globals. Multinational Business Review, 28(4), 447-461. https://doi.org/10.1108/MBR-102019-0123

Weerawardena, J., Mort, G. S., Salunke, S., Knight, G., \& Liesch, P. W. (2014). The role of the market sub-system and the socio-technical subsystem in innovation and firm performance: a dynamic capabilities approach. Journal of the Academy of Marketing Science, 43(2), 221-239. https://doi.org/10.1007/s11747-014-0382-9

Welch, C., Rumyantseva, M., \& Hewerdine, L. J. (2016). Using Case Research to Reconstruct Concepts. Organizational Research Methods, 19(1), 111-130.

https://doi.org/10.1177/1094428115596435

World Economic Forum. (2021). The great reset. Retrieved April 8, 2021, from Forum, World Economic website:

https://www.weforum.org/great-reset

Yin, R. (2003). Case Study Research: Design and Methods (5th ed.). Sage Publications.
Yin, R. K. (2009). Case Study Research: Design and Methods (5th ed.). Thousand Oaks: Sage.

Zahra, S. A. (2005). A theory of international new ventures: a decade of research. Journal of International Business Studies, 36(1), 20-28. https://doi.org/10.1057/palgrave.jibs.8400118

Zahra, S. A. (2021). International entrepreneurship in the post Covid world. Journal of World Business, 56(1), 101143. https://doi.org/10.1016/j.jwb.2020.101143

Zander, I., McDougall-Covin, P., \& Rose, E. (2015). Born globals and international business: Evolution of a field of research. Journal of International Business Studies, 46(1), 27-35. https://doi.org/10.1057/jibs.2014.60

Zhang, M. Y., \& Dodgson, M. (2007). "A roasted duck can still fly away": A case study of technology, nationality, culture and the rapid and early internationalization of the firm. Journal of World Business, 42(3), 336-349. https://doi.org/10.1016/j.jwb.2007.04.005 
Appendix A - List of Journals

\begin{tabular}{|c|c|}
\hline TOTAL ARTICLES & 99 \\
\hline Journal of International Entrepreneurship & 20 \\
\hline Journal of Small Business and Enterprise Development & 7 \\
\hline International Marketing Review & 6 \\
\hline International Business Review & 5 \\
\hline International Journal of Globalisation and Small Business & 4 \\
\hline Journal of World Business & 4 \\
\hline Management International review & 4 \\
\hline International Entrepreneurship and Management Journal & 3 \\
\hline International Journal of Entrepreneurial Behavior and Research & 3 \\
\hline International Small Business Journal & 3 \\
\hline Journal of International Marketing & 3 \\
\hline European Business Review & 2 \\
\hline International Journal of Entrepreneurial Venturing & 2 \\
\hline International Journal of Entrepreneurship and Small Business & 2 \\
\hline Journal of Business Research & 2 \\
\hline Journal of East-West Business & 2 \\
\hline Journal of Entrepreneurship in Emerging Economies & 2 \\
\hline Advances in International Marketing & 1 \\
\hline Asia Pacific Journal of management & 1 \\
\hline Competitiveness Review & 1 \\
\hline European Journal of International Management & 1 \\
\hline European Journal of Marketing & 1 \\
\hline Industrial Marketing Management & 1 \\
\hline International Journal of Emerging Markets & 1 \\
\hline International Journal of Entrepreneurship and Innovation Management & 1 \\
\hline International Journal of Foresight and Innovation Policy & 1 \\
\hline International Journal of Innovation Management & 1 \\
\hline Journal for Global Business Advancement & 1 \\
\hline Journal of Asia Business Studies & 1 \\
\hline Journal of Brand Management & 1 \\
\hline Journal of Business and Industrial Marketing & 1 \\
\hline Journal of East European Management Studies & 1 \\
\hline Journal of Marketing Channels & 1 \\
\hline Journal of the Academy of Marketing Science & 1 \\
\hline Long Range Planning & 1 \\
\hline Management Decision & 1 \\
\hline Management Research Review & 1 \\
\hline MIS Quarterly: Management Information Systems & 1 \\
\hline New Technology, Work and Employment & 1 \\
\hline
\end{tabular}




\begin{tabular}{l|l}
\hline Qualitative Market Research & 1 \\
\hline Scandinavian Journal of Management & 1 \\
\hline Thunderbird International Business Review & 1 \\
\hline
\end{tabular}

\section{ABOUT THE AUTHORS}

Pablo Leão - Fundação Getúlio Vargas - FGV, São Paulo, (Brasil). E-mail: pabloeleao@gmail.com Orcid id: https://orcid.org/0000-0002-5867-9461

Renato Souza Santos - Fundação Getúlio Vargas - FGV, São Paulo, (Brasil). E-mail: renato.renn@gmail.com Orcid id: https://orcid.org/0000-0002-1759-5640

\section{MELHORANDO A PESQUISA EM NOVAS EMPRESAS INTERNACIONAIS}

Pablo Leão, Renato Souza Santos

Fundação Getúlio Vargas - FGV, São Paulo, (Brasil)

\begin{tabular}{l}
\hline DETALHES DO ARTIGO \\
Histórico do Artigo: \\
Recebido em: 01 de Setembro de 2020 \\
Aceito: 30 de Março de 2021 \\
Disponível online: 01 de Maio de 2021 \\
Sistema de revisão “Double blind review” \\
Editor Científico \\
llan Avrichir \\
\hline
\end{tabular}

\section{Palavras-chaves:}

Empreendedorismo internacional Novos empreendimentos internacionais Rápida internacionalização Born global

\section{RESUMO}

Objetivo: Investigamos a literatura de internacionalização rápida para fornecer uma revisão da literatura sobre as pesquisas empíricas mais recentes sobre novos empreendimentos internacionais (INVs). Nós nos concentramos em relatar como a literatura sobre INVs evoluiu através das lentes de estudos de caso e destacamos questões sobre o uso dos conceitos de INVs.

Método: Realizamos uma revisão sistemática de 99 artigos de estudo de caso relacionados a novos empreendimentos internacionais publicados em periódicos de referência em todas as áreas do conhecimento da administração. Realizamos uma codificação em dois ciclos e uma análise temática.

Resultados principais: Descobrimos que os pesquisadores estão aplicando os conceitos INV e BG de forma intercambiável, portanto, incorretamente. Os estudiosos não consideraram nem discutiram as implicações teóricas de abandonar e adicionar critérios ao selecionar casos. Também descobrimos que a pesquisa no INV tem evoluído tematicamente à medida que os estudiosos têm estudado cada vez mais o momento pós-internacionalização dessas empresas.

Relevância / originalidade: Contribuímos com a literatura do INV, demonstrando que a teoria agora está evoluindo para entender o momento pós-internacionalização dessas empresas. Também discutimos a implicação de selecionar casos desconsiderando os critérios que os qualificam como INVs

Contribuições teóricas / metodológicas: Nossa pesquisa contribui com uma discussão sobre as implicações da aplicação livre dos conceitos de INVs e oferece insights sobre como a literatura evoluiu. 


\title{
MEJORA DE LA INVESTIGACIÓN SOBRE NUEVAS EMPRESAS INTERNACIONALES
}

\author{
Pablo Leão, Renato Souza Santos \\ Fundação Getúlio Vargas - FGV, São Paulo, (Brasil)
}

\begin{tabular}{|c|c|}
\hline HISTORIA DEL ARTÍCULO & RESUMEN \\
\hline $\begin{array}{l}\text { Historia del Artículo: } \\
\text { Recibido: } 01 \text { de Septiembre } 2020 \\
\text { Aceptado: } 30 \text { de marcha de } 2021 \\
\text { Disponible en línea: } 01 \text { de Mayo } 2021 \\
\text { Double Blind Review System } \\
\text { Editor Científico } \\
\text { Ilan Avrichir }\end{array}$ & $\begin{array}{l}\text { Objetivo: Profundizamos en la literatura sobre internacionalización rápida } \\
\text { para proporcionar una revisión de la literatura sobre las investigaciones } \\
\text { empíricas más recientes sobre nuevas empresas internacionales (INVs). } \\
\text { Nos enfocamos en informar cómo ha evolucionado la literatura sobre INV } \\
\text { a través de la lente de los estudios de casos, y destacamos cuestiones } \\
\text { sobre el uso de los conceptos de INV. } \\
\text { Método: Realizamos una revisión sistemática de } 99 \text { artículos de estudios } \\
\text { de caso relacionados con nuevos emprendimientos internacionales } \\
\text { publicados en revistas líderes en todas las áreas del conocimiento dentro } \\
\text { de la gestión. Realizamos una codificación de dos ciclos y un análisis } \\
\text { temático. } \\
\text { Resultados principales: Hemos encontrado que los investigadores están } \\
\text { aplicando los conceptos INV y BG de manera intercambiable, por lo tanto, } \\
\text { de manera incorrecta. Los académicos no han considerado ni discutido las } \\
\text { implicaciones teóricas de eliminar y agregar criterios al seleccionar casos. } \\
\text { También encontramos que la investigación en INV ha evolucionado } \\
\text { temáticamente a medida que los académicos han estudiado cada vez más } \\
\text { el momento posterior a la internacionalización de estas empresas. } \\
\text { Relevancia / originalidad: contribuimos a la literatura del INV demostrando } \\
\text { que la teoría está evolucionando para comprender el momento posterior } \\
\text { a la internacionalización de estas empresas. También discutimos la } \\
\text { implicación de seleccionar casos sin tener en cuenta los criterios que los } \\
\text { califican como INV. } \\
\text { Contribuciones teóricas / metodológicas: Nuestra investigación contribuye } \\
\text { con una discusión sobre las implicaciones de aplicar libremente los } \\
\text { conceptos de INV y ofrece ideas sobre cómo ha evolucionado la literatura. }\end{array}$ \\
\hline
\end{tabular}

\section{How to cite this article}

Leão, P., \& Santos, R. (2021). Moving Research on International new Ventures Forward: A Systematic Reviews on Case Studies. Internext, 16(2), 127-151. doi: http://dx.doi.org/10.18568/internext.v16i2.627 